\title{
Mortality rates of scleractinian corals before and during a mass bleaching event
}

\author{
Vicki J. Harriott* \\ Department of Marine Biology, James Cook University of North Queensland, Townsville 4811, Australia
}

\begin{abstract}
Mass bleaching of shallow-water corals was observed at Lizard Island and at other locations on the Great Barrier Reef in early 1982. In a patch-reef community at Lizard Island, mortality rates of scleractinian corals from 4 families were higher during the period of bleaching than during the previous year. It is postulated that bleaching may be the result of penetration of high levels of UV radiation during the time of maximum annual water temperature. Mortality rates varied amongst the coral species studied, and they were generally higher in smaller colonies. The coral mortality rates recorded are comparable with those reported in similar studies of reef-flat and reef-crest habitats
\end{abstract}

\section{INTRODUCTION}

Mortality rates are an integral part of the life-history strategies and population dynamics of scleractinian corals (Bak and Luckhurst, 1980), and have relevance to theories of community structure and diversity (Connell, 1973, 1978). There are few quantitative assessments of scleractinian coral mortality. Published estimates include those of Loya (1976a) for Stylophora pistillata in the Red Sea, and of Connell (1973) for a mixed species assemblage on Heron Reef. These studies were carried out predominantly in reef-flat and reef-crest habitats respectively. Potentially, such habitats are physically highly disturbed, and the high mortality rates reported might not be representative of coral communities in other habitats.

Bak and Luckhurst (1980) assessed mortality for colonies of several species over $30 \mathrm{~cm}$ in diameter at depths of 10 to $40 \mathrm{~m}$ at Curacao. The annual mortality rates of 2 to $19 \%$ reported by them were comparable with results of Connell (1973). Bak and Engel (1979), who studied mortality of juvenile corals $(<4 \mathrm{~cm})$, found annual mortality rates of approximately $50 \%$.

Loya (1976b) suggested that the pocilloporid Stylophora pistillata is an r-strategist because of its high mortality and recruitment rates. In contrast, Rosen (1981) concluded that corals may generally be consi-

\footnotetext{
- Present address: Sir George Fisher Centre for Tropical Marine Studies, James Cook University, Townsville, Australia
}

dered as relatively K-selected, or competitors/stresstolerators (sensu Grime, 1979), because of their longevity and low turnover.

In this study, mortality was assessed in 3 coral species and 1 species group. The species were selected to include a range of polyp sizes, growth forms and taxa, and their reproductive ecology was studied simultaneously (Harriott, $1983 \mathrm{a}, \mathrm{b}$ ). The study was carried out on a back reef area at depths of 2 to $9 \mathrm{~m}$, where physical conditions were probably intermediate between those prevailing during the studies of Connell (1973) and Bak and Luckhurst (1980).

The study period (Jan 1981 to May 1982) coincided with a period in early 1982 when widespread bleaching ( = loss of zooxanthellae) was reported in shallowwater corals from many areas of the Great Barrier Reef. A similar episode of widespread bleaching and mortality of corals was reported by Glynn (1983) to have occurred in the Gulf of Chiriqui, eastern Pacific Ocean, in early 1983. The mortality of the studied species during the bleaching event was quantified and compared to that for the $1 \mathrm{yr}$ period prior to the bleaching. Some causes of the bleaching are suggested.

\section{STUDY SITE AND METHODS}

The study site is a patch reef on the leeward side of the fringing reef surrounding Lizard Island and associated islands $\left(14^{\circ} 41^{\prime} \mathrm{S}, 144^{\circ} 28^{\prime} \mathrm{E}\right)$. The reef is approximately $50 \mathrm{~m}$ diameter, with water depths of approxi- 
mately $2 \mathrm{~m}$ on the reef top and of $9 \mathrm{~m}$ at the reef base at low water.

Rates of mortality and of partial mortality were assessed for Pocillopora damicornis (Linnaeus), Favia favus (Forskal), Lobophyllia corymbosa (Forskal) and the Porites lutea (Edwards and Haime)/australiensis (Vaughan) group. The latter 2 species could not be separated in the field; since their distribution, abundance and reproductive ecology were very similar (Harriott, 1983a, c), it was considered valid to pool the results obtained on them for an analysis of mortality rates.

On 8 January 1981, tags were attached to the substrate close to the first 20 colonies of each species observed during a random swim over the study site. The tags were plastic 'dymo' labels attached by plastic-coated copper wire. The locations of the colonies were mapped, and the largest diameter of each colony was measured to the nearest $1 \mathrm{~cm}$ diameter. Diameters of tagged colonies ranged from 1 to $55 \mathrm{~cm}$ for Pocillopora damicomis, 2 to $18 \mathrm{~cm}$ for Favia favus, 3 to $40 \mathrm{~cm}$ for Lobophyllia corymbosa, and 4 to $300 \mathrm{~cm}$ for Porites species. Depth of colonies ranged from 2 to $8 \mathrm{~m}$ at low tide.

On 7 April, 21 August and 2 December 1981, and on 7 May 1982, the tagged colonies were relocated and recorded as dead or alive. If a colony was alive, any partial mortality (Hughes and Jackson, 1980) was recorded. If a tag could not be located, one of two options was followed: Where a colony of the same species and size was found in the mapped position, the tag was assumed to have been destroyed and the colony was retagged. The most obvious source of tag loss was fish grazing. Where no tag or colony could be found, the colony was counted as 'lost', and was not included in the analyses. Because of this factor, the

Table 1. Pocillopora damicomis. Age estimated from colony diameter, annual mortality rates, and survival per 100,000 spat

\begin{tabular}{|cccc|}
\hline Year & $\begin{array}{c}\text { Range of } \\
\text { diameter } \\
\text { (cin) }\end{array}$ & $\begin{array}{c}\text { Annual } \\
\text { mortality } \\
(\%)\end{array}$ & $\begin{array}{c}\text { No. of } \\
\text { survivors per } \\
100,000 \text { spat }\end{array}$ \\
\hline 1 & 0.2 to 1 & 99.6 & 400 \\
2 & 1 to 4 & 64 & 144 \\
3 & 4 to 7 & 39 & 88 \\
4 & 7 to 12 & 39 & 54 \\
5 & 12 to 17 & 39 & 33 \\
6 & 17 to 22 & 20 & 26 \\
7 & 22 to 27 & 20 & 21 \\
8 & 27 to 32 & 20 & 17 \\
9 & 32 to 37 & 0 & 17 \\
10 & 37 to 42 & 0 & 17 \\
11 & 42 to 47 & 0 & 17 \\
12 & 47 to 52 & 0 & \\
\hline
\end{tabular}

mortality estimate derived was probably an underestimate, as it is likely that some of the 'lost' colonies were in fact dead. Lost colonies were noted in 8/83 records for Porites colonies, 3/83 for Pocillopora damicornis, 3/83 for Favia favus and 1/82 for Lobophyllia corymbosa. The rate of colony loss was very low for all species except for those of Porites. This is attributable to the fact that Porites was the most abundant coral genus at the study site, and it was frequently impossible to determine whether an untagged colony at a mapped location was the original colony.

For the purposes of this study, death was defined as either tissue death, or removal of the skeleton. It is probable that in some cases, breakage of skeletons results in living fragments (Highsmith, 1980, 1982) but these were considered to be recruits from asexual reproduction rather than a continuation of the original colony. Estimates of partial mortality rates were not included in mortality estimates, but were calculated separately.

When colonies died or were lost, an equivalent number of new colonies of a similar size were tagged to keep the sample size for each time interval close to 20. Thus, the total number of observations for each species was approximately 80 (20 colonies $\times 4$ samples periods).

For Pocillopora damicomis the age of each colony was estimated on the following basis: It was known from settlement experiments (Harriott, 1983c) that the diameter of a 1 yr old $P$. damicornis colony was approximately $\mathrm{lcm}$. Linear extension rates for colonies of $P$. damicornis with a diameter of $5 \mathrm{~cm}$ and above are approximately $2.5 \mathrm{~cm} \mathrm{yr}^{-1}$ (Stephenson and Stephenson, 1933; Buddemeier and Kinzie, 1976), and extension rates are less for smaller colonies (own obs.). Using this information, a relationship between diameter and age was obtained (Table 1). From these age estimates and the calculated mortality rates, a survivorship curve was calculated.

\section{RESULTS}

Of the colonies tagged in January 1981, 1/18 (5\%) of Favia favus, $2 / 13$ (15\%) of the Porites species, $4 / 20$ (20\%) of Lobophyllia corymbosa and 8/18 (44\%) of Pocillopora damicornis colonies died in the $16 \mathrm{mo}$ to May 1982. In cases where a colony survived between successive sampling periods, partial mortality was recorded in $1 / 71$ cases $(1.4 \%$ ) for Porites species, $2 / 79$ cases $(2.5 \%)$ for $F$. favus, $3 / 78$ cases $(3.8 \%$ ) for $L$. corymbosa and $6 / 66$ cases $(9.1 \%)$ for $P$. damicornis. These results include partial mortality of colonies that died in subsequent sampling periods. The relative 
rates of partial mortality for these species approximately parallel rates of absolute mortality.

When the number of living colonies at the beginning and end of a defined period is known, mortality for any other time period can be calculated using the following equations:

The instantaneous mortality rate $(m)$ can be calculated from survival data for a known period of time $\left(t_{1}\right)$

$$
\mathrm{m}=\frac{\ln \mathrm{Nt}_{1}-\ln \mathrm{N}_{\mathrm{O}}}{\mathrm{t}_{1}}
$$

The number of individuals surviving for a second period $\left(t_{2}\right)$ can be calculated from $m$

$$
\mathrm{Nt}_{2}=\mathrm{N}_{\mathrm{O}} \mathrm{e}^{\mathrm{mt}} 2
$$

Hence mortality rate can be calculated as

$$
\text { Mortality }=\frac{\mathrm{N}_{\mathrm{O}}-\mathrm{Nt}_{2}}{\mathrm{~N}_{\mathrm{O}}} \times 100 \%
$$

where $\mathrm{N}_{\mathrm{O}}=$ number of individuals at time $\mathrm{O}_{i} \mathrm{Nt}_{1}=$ number of individuals living at time $\mathrm{t}_{1} ; \mathrm{Nt}_{2}=$ number of individuals living at time $t_{2}$.

In this study, the length of the period between successive observations ranged from 3 to $5 \mathrm{mo}$. For each observation period and each species, the mortality rate for a standard 4 mo period was calculated (Table 2). All species showed some variation in mortality rate over the first 3 periods, but for each species, mortality was highest in the final observation period from December 1981 to May 1982.

Some bleached corals were observed in January 1982, and extensive bleaching was noted in March 1982. Zooxanthellae were absent from large areas of tissue in coral colonies at the study study site, at nearby reefs, and at reefs near Townsville (own obs.). Many small colonies were completely bleached and subsequently died, although many larger colonies regained zooxanthellae over subsequent months and recovered completely. In the Lizard Island area, bleaching occurred almost exclusively on the upper surface of corals, generally at depths of less than $5 \mathrm{~m}$, but occasionally in deeper waters where the water was clear. On branching colonies, the upper surfaces of branches were frequently bleached white, while the lower and any shaded surfaces of the same branches retained normal colouration.

In order to ascertain whether the bleaching coincided with an increase in coral mortality rate, the annual mortality rate was calculated from January 1981 to December 1981, i.e. before bleaching was observed, and from December 1981 to May 1982, i.e. during the period of bleaching. For all species, mortality was higher during the bleaching period than in the previous year: $58 \%$ vs. $31 \%$ for Pocillopora damicornis, $23 \%$ vs. $12 \%$ for Lobophyllia corymbosa, $15 \%$ vs. $5 \%$ for Porites species, and $12 \%$ vs. $0 \%$ for Favia favus. For all species pooled and for P. damicornis, frequencies of living and dead corals were significantly dependent on the time period $\left(\chi^{2}\right.$ contingency table analysis, $\left.P\left[\chi^{2}\right]<0.01\right)$. The number of dead corals was too low for the other species to permit testing.

The rate of partial mortality was also higher during the bleaching period, e.g. for Pocillopora damicornis 4 of the 6 records of partial mortality occurred from December 1981 to May 1982, compared with 1,0 and 1 record in each of the other 3 sample periods.

To ascertain the relationship between mortality rate and size, colonies of each species were allotted to a size class, the range of which depended on the size range of the species, and the annual mortality rate was calculated for each size class. In general, mortality decreased with increasing size class, indicating that smaller individuals are more susceptible to mortality than larger ones (Fig. 1). For Pocillopora damicornis the plot was extended by including data on the mortality rate of 2 mo old spat in the field (Harriatt, 1983b). The spat mortality rate of $60 \%$ for 2 mo gives an overall annual mortality rate of $99.6 \%$. Similar data were not available for the other species.

Using the procedure for age determination outlined above, ages were assigned to Pocillopora damicornis colonies according to their sizes. Mortality-rate estimates for each size class were applied and a survivorship curve from 0 to 12 yr for 100,000 newly settled spat was calculated (Fig. 2). Despite the inherent simplifications in age determination and size-related mortality

\begin{tabular}{|c|c|c|c|c|c|c|c|c|}
\hline \multirow[t]{2}{*}{ Species } & \multicolumn{2}{|c|}{$\begin{array}{c}\text { Jan } 81 \text { to } \\
\text { Apr } 81\end{array}$} & \multicolumn{2}{|c|}{$\begin{array}{l}\text { Apr } 81 \text { to } \\
\text { Aug } 81\end{array}$} & \multicolumn{2}{|c|}{$\begin{array}{l}\text { Aug } 81 \text { to } \\
\text { Dec } 81\end{array}$} & \multicolumn{2}{|c|}{$\begin{array}{c}\text { Dec } 81 \text { to } \\
\text { May } 82\end{array}$} \\
\hline & $\mathrm{n}$ & $\mathrm{M}$ & $\mathrm{n}$ & M & $\mathrm{n}$ & $M$ & $\mathrm{n}$ & M \\
\hline Pocillopora damicomis & 20 & 0 & 20 & 18 & 20 & 17 & 19 & 26 \\
\hline Lobophyllia corymbosa & 20 & 7 & 21 & 0 & 21 & 5 & 19 & 9 \\
\hline Porites species & 20 & 0 & 18 & 5 & 20 & 0 & 15 & 5 \\
\hline Favia favus & 19 & 0 & 21 & 0 & 21 & 0 & 19 & 4 \\
\hline
\end{tabular}

Table 2. Standardised 4 -monthly mortality rates for the 4 coral species studied during the 4 sample periods. $\mathrm{n}=$ sample size; $\mathrm{M}=$ mortality rate $(\%)$ 


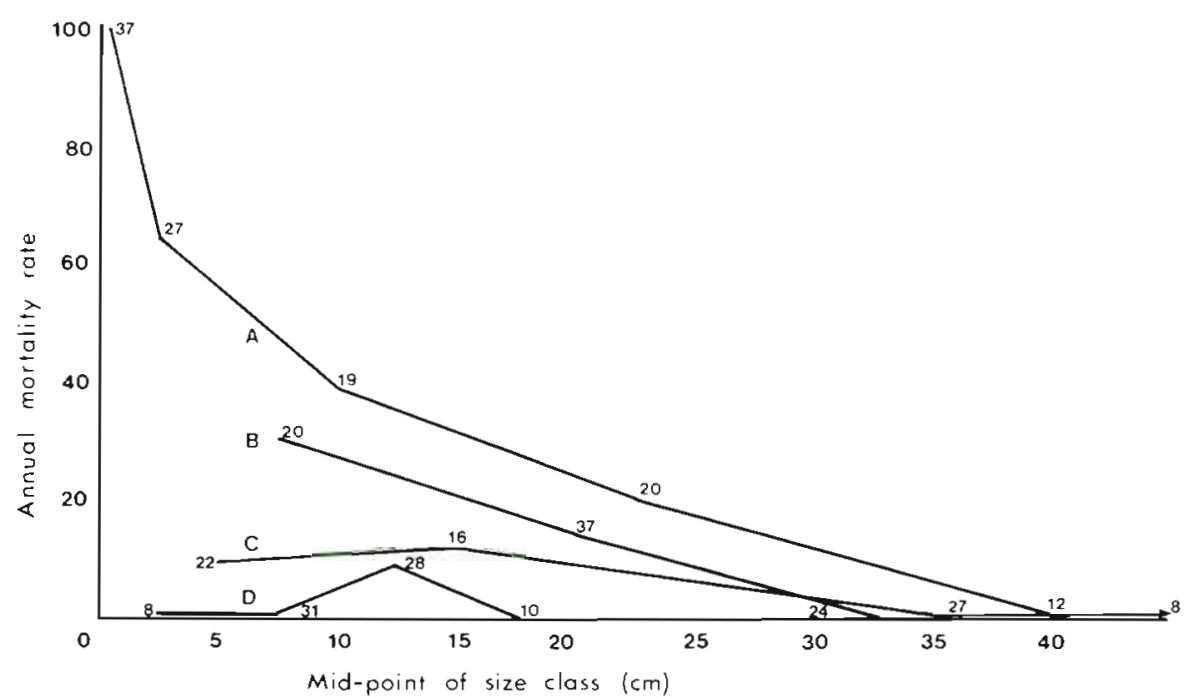

Fig. 1. Pocillopora damicornis (A), Lobophyllia corymbosa (B), massive Porites species (C), and Favia favus (D). Changes in mortality rate with colony size. Annual mortality rate for each size class, where size is the maximum diameter, is plotted against the mid-point of the size class. Number of observations given near each data point

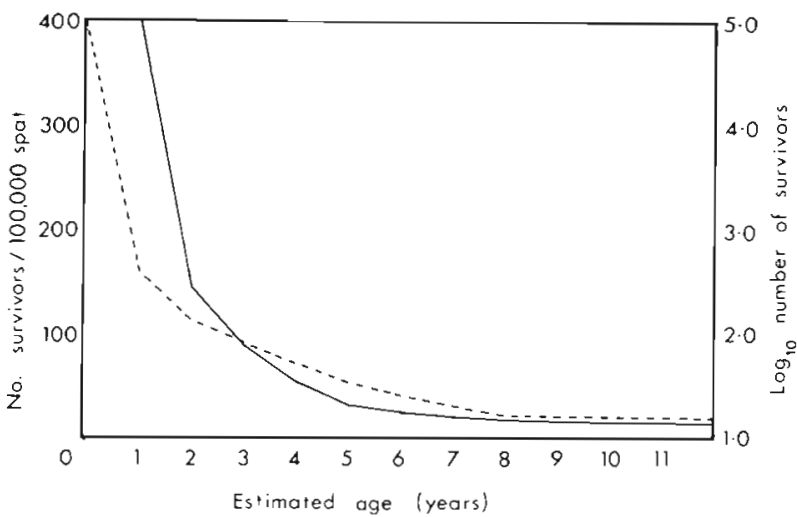

Fig. 2. Pocillopora damicornis. Survivorship curve from untransformed data (solid line) and on a log scale (dashed line)

(Connell, 1973; Hughes and Jackson, 1980), the method produced a good representation of a Type 3 survivorship curve, i.e. increasing survivorship with increasing age (Deevey, 1947), when results were plotted both untransformed and as a semi-log transformation (Fig. 2).

\section{DISCUSSION}

\section{Causes of mortality}

Mortality rates of the 5 scleractinian coral species showed (a) variation in magnitude amongst different species, (b) temporal variation and (c) a decrease with increasing size class.

The most commonly observed causes of mortality and partial mortality were:
(1) Physical damage as a result of wave action, bioerosion, or both, produced colonies that had been overturned or broken into fragments.

(2) Predators, in particular grazing fish and the sea star Acanthaster planci, were frequently seen to damage living corals. Generally, predation caused damage to only part of a colony, but death of the entire colony sometimes resulted, particularly in small colonies. Scarid grazing most commonly affected Porites species, leaving series of parallel teeth marks on the surface of the colonies (Glynn et al., 1972; own obs.). Acanthaster planci was present in low-to-moderate numbers ( 0 to $2100 \mathrm{~m}^{-2}$ ) throughout the study; they preyed on many species, but affected Acropora species most frequently.

(3) Tissue death by infection or unknown causes was occasionally observed, particularly in small Pocillopora damicornis colonies.

(4) The factors that caused mass bleaching of coral colonies between December 1981 and April 1982 resulted in increased mortality of the coral colonies.

A report of a bleaching episode of even greater magnitude than that discussed here was given by Glynn (1983). In January to April 1983, reefs in an area of about $10,000 \mathrm{~km}^{2}$ in the Gulf of Chiriqui were bleached of zooxanthellae with subsequent high mortality ( 80 to $90 \%$ ). The cause of the bleaching could not be identified and a range of man-related and natural disturbances were implicated. The widespread nature and severity of these bleaching events lend importance to the search for a causative factor or factors.

Extensive loss of zooxanthellae by corals has previously been reported as a response to stress such as high 


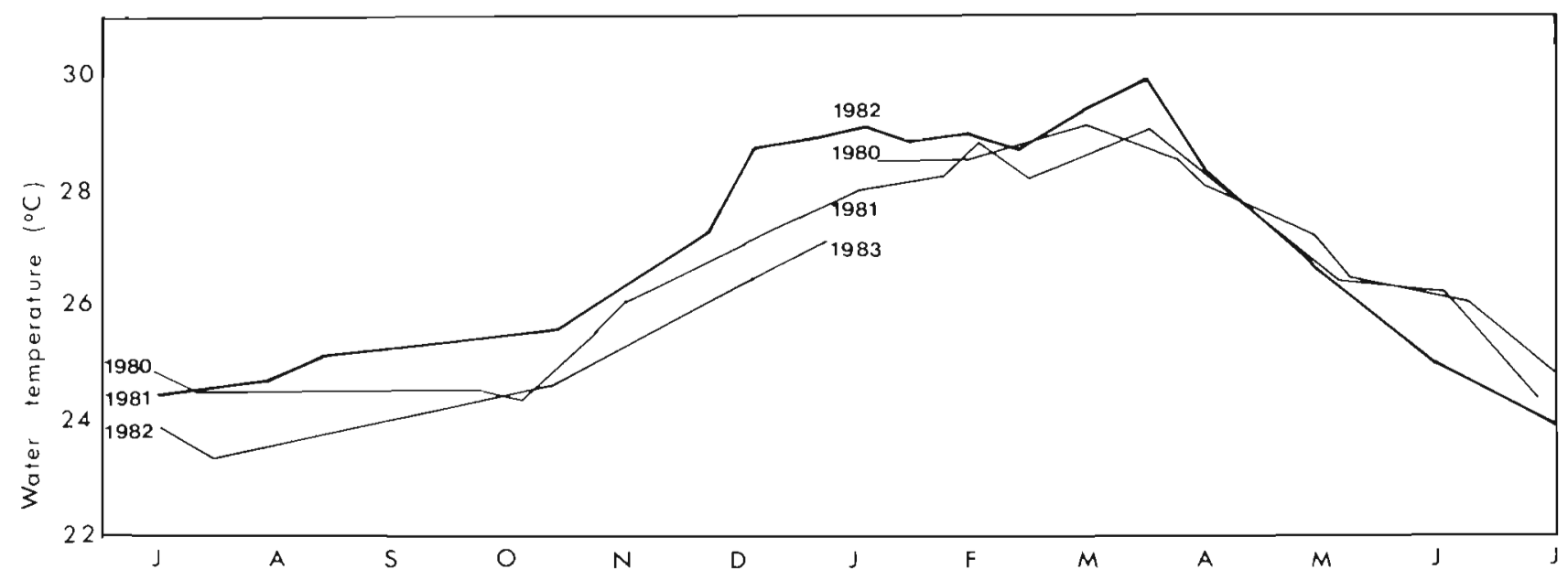

Fig. 3. Water temperature at $10 \mathrm{~m}$ in the open water near Lizard Island from Jan 1980 to Dec 1983. Heavy line: water temperature before and during mass bleaching event. Data supplied by the CSIRO Division of Fisheries and Oceanography, Cronulla, Australia

temperature (Shinn, 1966; Jokiel and Coles, 1974, 1977; Coles, et al., 1976; Japp, 1979), fresh-water influx (Goreau, 1964; Egana and DiSalvo, 1982), and extended darkness (Yonge and Nicholls, 1931; Franzisket, 1970).

In the Great Barrier Reef episode reported here, the stress that caused the bleaching seems to have been radiation, since the bleaching occurred only on the upper and unshaded surfaces of colonies, and since the bleaching was restricted to colonies in shallow or very clear waters. The bleaching occurred during a summer of unusually low rainfall and higher-than-average hours of sunshine (Table 3), and during the period of the year when water temperature was very high (Fig. 3). Siebeck (1981) and Jokiel and York (1982) have discussed the potentially damaging effects of UV radiation on corals, and the significance of the presence of UV blocking agent in coral tissue (Shibata, 1969). Unusually high levels of UV radiation are a possible cause of bleaching in this case, although no measurements of UV irradiance levels are available for the period and location.

Detrimental synergistic effects of environmental var- iables have been reported by Coles and Jokiel (1978). They noted that interactions between physical factors are most important near the limits of tolerance of a given factor. The bleaching in this case occurred during the period of highest water temperature, which may in itself stress corals (e. g. Jokiel and Coles, 1974, 1977). Water temperature at Lizard Island during late 1981 and early 1982 was higher than for the same period in the other 2 yr for which data are available (Fig. 3).

\section{Life-history strategies}

The mortality rates found in this study are comparable with those reported by Loya (1976a) of about $30 \%$ annual mortality for the pocilloporid Stylophora pistillata, and with those of Connell (1973) of 0 to $30 \%$ annually in a mixed-species population. Bak and Luckhurst (1980) reported a somewhat lower mortality rate ( 2 to $19 \%$ ) but this may be associated with the larger size of colonies in their samples $(>30 \mathrm{~cm}$ diameter).

Mortality rate varied among species in the present

Table 3. Rainfall and sunshine hours in the 4 mo before and during the mass bleaching event, and the averages and/or median values for the previous 34 yr (data supplied by the Bureau of Meterology for the Townsville region)

\begin{tabular}{|lccccc|}
\hline Month & \multicolumn{3}{c}{ Rainfall } & \multicolumn{2}{c|}{ Hours of sunshine } \\
\cline { 2 - 5 } & $\begin{array}{c}34 \mathrm{yr} \\
\text { median }\end{array}$ & $\begin{array}{c}34 \mathrm{yr} \\
\text { average }\end{array}$ & $\begin{array}{c}\text { Bleaching } \\
\text { period }\end{array}$ & $\begin{array}{c}34 \text { yr } \\
\text { average }\end{array}$ & $\begin{array}{c}\text { Bleaching } \\
\text { period }\end{array}$ \\
\hline Dec'81 & 62 & 111 & $61(-45 \%)$ & 263 & $304(+16 \%)$ \\
Jan '82 & 222 & 305 & $164(-46 \%)$ & 227 & $271(+19 \%)$ \\
Feb '82 & 301 & 330 & $182(-45 \%)$ & 204 & $247(+21 \%)$ \\
Mar' '82 & 204 & 233 & $113(-52 \%)$ & 221 & $244(+10 \%)$ \\
Totals & & $520(-47 \%)$ & 915 & $1066(+17 \%)$ \\
\hline
\end{tabular}


study. Mortality of Pocillopora damicomis was greater than that of any other species at all size classes (Fig. 2). Mortality for Favia favus and Porites species was low, that of Lobophyllia corymbosa intermediate. Franzisket (1970) noted that $P$. verrucosa (called $P$. elegans) exhibited a high mortality in the absence of light, relative to 3 other coral species. He correlated this high mortality with a high metabolic rate, and concluded that the species' stringent ecological requirements made it poorly adapted to withstand environmental change. Similarly, Jokiel and Coles (1974) found that $p$. meandrina showed a low tolerance for artificially raised temperatures, relative to other species, and Glynn (1976) found higher mortality rates for $P$. damicomis than for other species in both field and experimental situations. Pocillopora species probably expend large amounts of energy on the production of large, well-developed planulae; in a related study, $P$. damicornis was highly successful at recruitment, relative to its abundance (Harriott, 1983c). In this manner, its population can be maintained despite high mortality rates, and narrow physiological tolerances, i.e. there is a trade-off between reproductive effort, maintenance and mortality (Law, 1979).

Rosen (1981) stated that zooxanthellate corals in general are remarkable for their longevity and low turnover; that is, on an $\mathrm{r} / \mathrm{K}$ life history spectrum they are relatively $\mathrm{K}$ selected (Stearns, 1976), and they are competitors or stress tolerators rather than ruderals (Grime, 1979). In this study, the coral species studied exhibited a range of mortality rates that varied from very high (approx. $40 \% \mathrm{yr}^{-1}$ ) to very low (less than $5 \%$ $\mathrm{yr}^{-1}$ ). The corals also exhibited a range of recruitment success in a concurrent experiment (Harriott, 1983c). Thus Rosen's assumption of uniformly low recruitment and mortality in corals may be an over-simplification.

Certainly, Pocillopora damicornis, and the other pocilloporid Stylophora pistillata, have life-history features which places them on the r-selected/ ruderal extreme of a life-history spectrum (Loya, 1976 b), at least in terms of mortality rate and recruitment success. On the other hand, coral species abundant in turbid or low-light habitats are probably stress tolerant, while those with digestive dominance or overshading abilities (Lang, 1970, 1973; Connell, 1973) may be good competitors (sensu Grime, 1979).

\section{Survivorship}

Coral mortality rates generally decreased with increasing colony size. A similar relationship was found by both Connell (1973) and Loya (1976 a). Bak and Engel (1979) reported an annual mortality of over $50 \%$ for corals $<4 \mathrm{~cm}$ diameter $(1 / 3$ of colonies died in a 6 mo period), far higher than the comparable annual mortality of an adult population (2 to $19 \%$, Bak and Luckhurst, 1980). Small colonies are more susceptible to most factors causing tissue death than larger ones, possibly because the area of tissue remaining following damage is too small to regenerate.

The survivorship curve for Pocillopora damicornis is the typical Type 3 curve of Deevey (1947) that would be expected for a marine organism producing numerous small offspring, i.e. very high mortality in juveniles and decreasing mortality rates with increasing age. Survivorship curves for the other scleractinian species studied here would be expected to follow a similar pattern if data were available for the early stages. This contrasts with the survivorship curve for the temperate coral Balanophyllia elegans from California (Fadlallah, 1983). B. elegans releases rapidly settling nonpelagic larvae with low mortality, and has a Type 2 survivorship curve, i. e. mortality rate is similar throughout the life cycle. The reproductive ecology of $B$. elegans contrasts with all other cases reported for tropical coral species (Kojis and Quinn, 1981a, b, 1982; Harriott, 1983a; Harrison et al., 1984).

\section{Ecological consequences}

The relatively high mortality established for several coral species in this study supports a concept of generally high turnover in scleractinian communities. The results of Loya (1976 a) and Connell (1973), obtained in shallow-water reef-flat habitats, are shown here to be consistent with results from deeper and more sheltered waters. A similar pattern of relatively high mortality and changes in the spatial relationships of living corals was demonstrated by Bak and Luckhurst (1980) in a physically less disturbed habitat than the one described here.

These results contribute to the small amount of baseline data on 'natural' mortality in corals that can be compared with estimates of coral mortality following some unusual phenomenon, such as a mass bleaching or pollution event. Occasional mass mortality can influence the abundance and distribution of organisms as much as, or more than, the normally encountered day-to-day mortality (Fishelson, 1973; Yamaguchi, 1975; Loya, 1976 c; Glynn, 1983). Such events might prevent long-term survival of some species in areas where their normal physiological tolerances are exceeded only occasionally, particularly if they recruit infrequently.

Acknowledgements. I thank David Fisk, James Oliver, Russell Reichelt and my colleagues at James Cook University for assistance and comments on the manuscript. The research 
was funded by a Commonwealth Postgraduate Research Award and research grants from the Australian Museum and the Australian Coral Reef Society. I thank the CSIRO Division of Fisheries and Oceanography, Cronulla and the Bureau of Meterology, Townsville for the use of water-temperature and meterological data. The use of the facilities of the Lizard Island Research Station is gratefully acknowledged.

\section{LITERATURE CITED}

Bak, R. P. M., Engel, M. S. (1979). Distribution, abundance and survival of juvenile hermatypic corals (Scleractinia) and the importance of life history strategies in the parent coral community. Mar. Biol. 54 (4): 341-352

Bak, R. P. M., Luckhurst, B. E. (1980). Constancy and change in coral reef habitats along depth gradients at Curacao. Oecologia 47 (2): 145-155

Buddemeier, R. W., Kinzie, R. A. III (1976). Coral growth. Oceanogr. Mar. Biol. A. Rev. 14: 183-225

Coles, S. L., Jokiel, P. L. (1978). Synergistic effects of temperature, salinity and light on the hermatypic coral Montipora verrucosa (Lamarck). Mar. Biol. 49: 187-195

Coles, S. L., Jokiel, P. L., Lewis, C. R. (1976). Thermal tolerance in tropical versus subtropical Pacific reef corals. Pacif. Sci. 30: 159-166

Connell, J. H. (1973). Population ecology of reef-building corals. In: Jones, O. A., Endean, R. (ed.) Biology and geology of coral reefs, Vol. 2. Academic Press, New York, p. $205-245$

Connell, J. H. (1978). Diversity in tropical rain forests and coral reefs. Science, N. Y. 199: 1302-1310

Deevey, E. S. (1947). Life tables for natural populations of animals. Q. Rev. Biol. 22: 283-314

Egana, A. C., DiSalvo, L. H. (1982). Mass expulsion of zooxanthellae by Easter Island corals. Pacif. Sci. 36: 61-63

Fadlallah, Y. H. (1983). Population dynamics and life history of a solitary coral, Balanophyllia elegans, from central California. Oecologia 58: 200-207

Fishelson, L. (1973). Ecological and biological phenomena influencing coral-species composition on the reef tables at Eilat (Gulf of Aqaba, Red Sea). Mar. Biol. 19: 183-196

Franzisket, L. (1970). The atrophy of hermatypic reef corals maintained in the darkness and their subsequent regeneration in light. Int. Revue ges. Hydrobiol. 55: 1-12

Glynn, P. W. (1976). Some physical and biological determinants of coral community structure in the eastern Pacific. Ecol. Monogr. 46 (4): 431-456

Glynn, P. W. (1983). Extensive 'bleaching' and death of reef coral on the Pacific coast of Panama. Environ. Conserv. 10: $149-154$

Glynn, P. W., Stewart, R. H., McCosker, J. E. (1972). Pacific coral reefs in Panama: structure, distribution and predators. Geol. Rundsch. 61: 483-519

Goreau, T. F. (1964). Mass expulsion of zooxanthellae from Jamaican reef communities after Hurricane Flora. Science, N. Y. 145: 383-386

Grime, J. P. (1979). Plant strategies and vegetation processes. John Wiley and Sons, Chichester

Harriott, V. J. (1983 a). Reproductive ecology of four scleractinian species at Lizard Island, Great Barrier Reef. Coral Reefs 2: 9-18

Harriott, V. J. (1983 b). Reproductive seasonality, settlement and post-settlement mortality of Pocillopora damicornis. Coral Reefs 2: 151-157

Harriott, V. J. (1983 c). Reproductive ecology and population dynamics in a scleractinain coral community. Ph. D. thesis, James Cook University of North Queensland, Australia

Harrison, P. L., Babcock, R. C., Bull, G. D., Oliver, J. K., Wallace, C. C., Willis, B. L. (1984). Mass spawning in tropical reef corals. Science, N. Y. 223: 1186-1189

Highsmith, R. C. (1980). Passive colonization and asexual colony multiplication in the massive coral Porites lutea Milne Edwards and Haime. J. exp. mar. Biol. Ecol. 47: $55-67$

Highsmith, R. C. (1982). Reproduction by fragmentation in corals. Mar. Ecol. Prog. Ser. 7: 207-226

Hughes, T. P., Jackson, J. B. C. (1980). Do corals lie about their age? Some demographic consequences of partial mortality, fission and fusion. Science, N. Y., 209; 713-715

Jaap, W. C. (1979). Observations on zooxanthellae expulsion on middle Sambo reef, Florida Keys. Bull. mar. Sci. 29: $414-422$

Jokiel, P. L., Coles, S. L. (1974). Effects of heated effluent on hermatypic corals at Kahe Point, Oahu. Pacif. Sci. 28: 1-18

Jokiel, P. L., Coles, S. L. (1977). Effects of temperature on the mortality and growth of Hawaiian reef corals. Mar. Biol. 43: 201-208

Jokiel, P. L., York, R. H. Jnr. (1982). Solar ultraviolet photobiology of the reef coral Pocillopora damicornis and symbiotic zooxanthellae. Bull. mar. Sci. 32: 301-315

Kojis, B. L., Quinn, N. J. (1981 a). Aspects of sexual reproduction and larval development in the shallow water hermatypic coral Goniastrea australensis (Edward and Haime, 1857). Bull. mar. Sci. 31:558-573

Kojis, B. L., Quinn, N. J. (1981 b). Reproductive strategies in four species of Porites (Scleractinia). Proceedings of 4 th International Caral Reef Symposium, Manila, Philippines, Vol. 2: 145-151

Kojis, B. L., Quinn, N. J. (1982). Reproductive ecology of two faviid corals (Coelenterata: Scleractinia). Mar. Ecol. Prog. Ser. 8: 251-255

Lang, J. C. (1970). Interspecific aggression in scleractinian corals. I The rediscovery of Scolymia cubensis. Bull. mar. Sci. 21: 952-959

Lang, J. C. (1973). Interspecific aggression in scleractinain corals. II Why the race is not only to the swift. Bull. mar. Sci. 23: 260-279

Law, R. (1979). Ecological determinants in the evolution of life histories. In: Anderson, R. M., Turner, B. D., Taylor, L. R. (ed.) Population dynamics. Blackwell Scientific Publ., Oxford, p. 81-103

Loya, Y. (1976 a). Settlement, mortality and recruitment of a Red Sea scleractinian coral population. In: Mackie, G. O. (ed.) Coelenterate ecology and behaviour. Plenum Press, New York, p. 89-100

Loya, Y. (1976 b). The Red Sea coral Stylophora pistillata is an r strategist. Nature, Lond, 259: 478-480

Loya, Y. (1976 c). Recolonization of Red Sea corals affected by natural catastrophes and man-made perturbations. Ecology 57 : 278-289

Rosen, B. R. (1981). The tropical high diversity enigma - the coral's eye view. In: Forey, D. L. (ed.) The evolving biosphere. British Museum (Natural History), Cambridge University Press, Cambridge, p. 103-130

Shibata, K. (1969). Pigments and a UV-absorbing substance in corals and a blue-green algae living in the Great Barrier Reef, Australia. Plant Cell Physiol. 10: 325-335

Shinn, E. A. (1966). Coral growth rate, an environmental indicator. J. Paleont. 40 (2) : 233-240

Siebeck, O. (1981). Photoreactivation and depth dependent UV tolerance in a reef coral in the Great Barrier Reef, Australia. Naturwissenschaften 68: 426-428 
Stearns, S. C. (1976). Life history tactics; a review of the ideas. Q. Rev. Biol. 51: 3-47

Stephenson, T. A., Stephenson, A. (1933). Growth and asexual reproduction in corals. Scient. Rep. Gt Barrier Reef Exped. 3: $167-271$

Yamaguchi, M. (1975). Sea level fluctuations and mass mor- tality of reef animals in Guam, Mariana Is. Micronesia 11 (2): $227-243$

Yonge, C. M., Nicholls, A. G. (1931). Studies on the physiology of corals $\mathrm{V}$. The effects of starvation in light and in darkness on the relationship between corals and zooxanthellae. Scient. Rep. Gt Barrier Reef Exped. 1: 177-211

This paper was presented by Dr. R. P. M. Bak; it was accepted for printing on August 21, 1984 